\title{
AVRUPA VE MODERNITE SARMALINDA \\ BİR İSLAM ARAYIŞI OLARAK: EURO-İSLAM
}

\begin{abstract}
Ahmet DAĞ*
Öz

Batının ilerlemesinde Protestanlık önemli etkenlerden biri olarak görülür. Bu bağlamda İslam'ın reforma edilmesi gerektiğine dair Luther ve Protestanlık vurgusunda bulunulur. $\mathrm{Bu}$ vurgu, gerek Müslüman gerekse gayri-Müslim teolog ve düşünürler tarafindan dile getirilir. Özellikle doğu blokunun yıkılışıyla (1990 sonrası) komünizmin bir tehdit olmaktan çıkmas1, Müslüman nüfusun Avrupa'da önemli bir orana yaklaşması, İslam'ın ve Müslümanların bir sorun olduğu yaklaşımını doğurmuştur. Çağdaş Batı uygarlığının yaşam tarzına bir tehdit olarak görülen İslam ve Müslümanların yeni bir form kazanması için farklı yaklaşımlar sunulmuştur. Bu yaklaşımlardan biri olan Euro-İslam; modernite sarmalında olan dünyadan ehlileştirilmiş ve çok kültürlülük, hoşgörü, seküler ve kültürel modernliği içeren bir din anlayışıdır. İslam, Avrupalı değerlere uygun hale getirmeye çalışılmaktadır. Nitekim Fransa'da gündemde olan "Fransa İslam'ı” böyle bir çabanın göstergesidir. Avrupa'nın İslamlaşması-İslam'ın Avrupalılaşması, Eurobia-Euro-İslam dualitesinde yeni bir arayış ve yaklaşım olan Euro-İslam'ın imkân ve zaafları vardır. Bu makalede Euro-İslam'ın Lutheryen bir hareket olup olmadığına, tarihsel dikotomik yaklaşıma sahip Avrupa'nın yaklaşımına değinilecektir.
\end{abstract}

Anahtar Kelimeler: Euro-İslam, Luther, İslam’ın Avrupalılaşması, Müslüman göçmenler.

\section{Europe and the Search for Islam in the Spiral of Modernity: Euro-Islam}

* Doç. Dr., Kırklareli Üniversitesi, Fen-Edebiyat Fakültesi, Felsefe Bölümü, adag29@ yahoo.com 


\begin{abstract}
Protestantism is seen as one of the important factors in the development of the West. In this context, Luther and Protestantism are emphasized in Islam should be reformed. This emphasis is expressed by both Muslim and non-Muslim theologians and thinkers. Both communism's becoming not a threat anymore and the Muslim population's approaching to important rate in Europe especially after the collapse of the Eastern Bloc (1990) have generated the idea that Islam and Muslims are a problem. Different approaches have been presented for Islam and Muslims, who are perceived as a threat and problem to the way of life of contemporary Western civilization, are to gain a new form. Euro-Islam, one of these approaches, is an understanding of religion that is tame from the world and is multicultural, tolerant, secular and cultural modernized. Islam is being trying to bring it into line with European values. As a matter of fact, "Islam in France" which is on the agenda in France is a sign of such effort. The Islamization of Europe - the Europeanization of Islam and the Eurabia-Euro-Islamic duality have a possibility and weakness of Euro-Islam, a new quest and approach. In this article, whether Euro-Islam is a Lutheran move-ment, the approach of Europe with historical dichotomical approach will be mentioned.
\end{abstract}

Keywords: Euro-Islam, Luther, Europeanization of Islam, Muslim immigrants.

\title{
Giriş
}

İlerleme-gerileme ikilemi içinde Rönesans ve Avrupa'nın gelişimiyle aynı düzlemde doğan teolog Luther ve ardılı bir hareket olan Protestanlık, Avrupa'nın dolayısıyla Batının gelişmesinin en önemli nedenlerinden biri olarak görülmüştür. Büyük filozoflardan W. F. Nietzsche, modern insanın sorununun nedenlerlesonuçların karıştırılması olduğunu söylemiştir. (Nietzsche, 2010: 49). Luther'in reformculuğu veya Protestanlık, Batının gelişmesinin nedeni olmaktan daha çok Rönesans ve sonrasında Batı'da meydana gelen gelişimin bir neticesidir. Nitekim ülkemizde geri kalma nedenini dine/İslam’a veya Batının ilerlemesini Protestanlığa bağlamak düşülen en önemli yanılgılardan biridir. Bu yanılgı, sürekli Luther'e veya Protestanlığa atıflar yapılmasına yol açmıştır. Nitekim W. C. Smith, reform taraf- 
tarlarının Eş'ari'den, Gazali'den veya İkbal'den daha çok Luther'e atıfta bulunmalarının şaşırtıcı olduğunu ifade eder (Smith, 1953: 19).

Bu bağlamda İslam'ın ve Müslümanların Martin Luther'e ihtiyaç duyulduğunu ifade eden Müslüman, gayri Müslim yazar ve düşünürler vardır. Luthercilik veya Protestanlık teolojisi, Müslüman yazar ve düşünürlerin sıklıkla atıfta bulunduğu bir olgu haline gelmiştir. İslam'ın ve Müslümanların karşı karşıya kalmış olduğu isnat ve suçlamalar, apolojist bir tutum ve yeni yaklaşımlar edinilmesine yol açmıştır. Demokrasiye, ticari kapitalizme, hoşgörülü/tolerans ve diyalojik topluma, seküler, özgürlükçü ve ilerlemeci oluşumlara zemin oluşturduğu iddia edilen Protestanlığın model bir mezhep, Luther'in ise bir rol model olarak görülmesi söz konusu olmuştur.

İslam'a yönelik çok sert açıklamalarda bulunan kişiler Selman Rüşdi ve Ayaan Hırsi Ali gibi kişiler "Luther" olarak görülürken Müslümanların yaşamış olduğu sorunlardan dolayı çözüm arayan kişiler de "Lutherci" sayılmışlardır. İslam coğrafyasında birçok kişinin Luther olarak atfedilmesine karşın Protestanlık gibi bir hizip veya topluluk ise yok denecek kadar azdır. Protestanlık mezhebine benzer bir mezhep olarak İngilizlere sadakatle bağlı (loyalizm) ve eğitim felsefesi Batı’ya endeksli olan Ahmediler görülmüştür. Bu mezhebin lideri Gulam Ahmed Han, sadece İngilizlerin yanında olmakla kalmamış aynı zamanda Hindistan'ın da bir Luther'e ihtiyacı olduğu temel kabulünden hareketle, İslâm düşüncesinin reforme edilmesi gerektiği fikrini savunmuştur (Öztürk, 2003: 174). Küreselleşme şartlarından faydalanarak kendine zemin oluşturan hoşgörü merkezli, çoklu etnik, rrk ve kültürel bir yapı inşa etmek amacında olmuş ve kendilerini İslâm içerisinde yenilikçi bir hareket olarak niteleyen Ahmediyye düşüncesi mensupları küresel bağlamda misyonerliğin daha da ileri götürülmüş hali olarak ortaya çıkmışlardır (Farajae, 2013: 276).

İslam'dan bir Protestanlık modeli hareket veya rol model figürü olabilecek kişi çıkarma, yalnızca içinde yaşadıkları sorunlardan dolayı açmazları aşmak isteyen ve çözüm arayan Müslüman toplumların ve kişilerin değil, İslam'ın mevcut 
haliyle "sorunlu" olduğunu düşünen devletler, toplumlar, medya, düşünür ve yazarların da beklentisidir. Bu makalede bir beklenti olan Euro-İslam'ın Protestanlık'la ve temsilcilerinin ise Luther ile olan benzerliklerine, farklılarına, neliğine ve sorunlarına değinilecektir.

\section{Euro-İslam Lutheryen veya Protestan Bir Hareket midir?}

Kriz ve karışıklık dönemlerinde toplumlar, mevcut hâkim gücün yaşadıklar1 ve pratikleri üzerinden kendi sorunlarını aşmaya çalışırlar ki bu usul doğru ve hakiki sonuçlar verme ihtimali zayıf olan bir usuldür. Yeni bir Luther isteği ve reformist hareket talebi yeni bir öykü değildir. C. Kurzer ve. M. Browers gibi Amerikalı akademisyenler 20. yüzyılın başında İslam coğrafyası için reformculuğun gerekliliğine vurguda bulunmuşlardır. Muhafazakâr gazeteciler, Müslüman Lutherleri araştırmaya liberal akademisyenler kadar isteklidir. New York Time's'ın köşe yazarı T. L. Friedman, 2002 yılında İslami reform için çağrıda bulunmuştur (Friedman, 2002).

Yalnızca dışarıdan teklifler ve vazifeler söz konusu değil, bir metot ve amaç olarak bu düşünceyi taşıyan İslam dünyasının farklı ülkelerinden kişiler de söz konusudur. Bunlardan biri olan Misırlı bir Müslüman olan Hamid Abdülsamed, Luther'in kutsal metnin özüne dönme çabasıyla Hıristiyanlığı reforme ettiğini İslam'da da böyle bir çabanın İslam'ı hatta İslamcıların konumunu güçlendireceğini ifade eder. Yine kendi tabiriyle "Her Müslüman bir Luther olmalı" ilkesini okutan Lübnan asıllı akademisyen Mouhanad Khorchide de alenen reformcu bir yaklaşıma sahip olanlardan biridir (Gülyeşil, 2017).

Oysa Protestanlığın ve Luther'in varlığını ortaya koyan coğrafi, siyasi, sosyal, kültürel ve iktisadi nedenler ile şu an Müslümanların yaşamış olduğu vasat ve şartlar arasında çok az benzerlikler vardır. Hem Batı siyasal gerçekliği hem de Hıristiyanlığın yaşadığı din gerçekliği ile İslam dünyasının yaşadığı siyasî ve dinî gerçeklik tamamen birbirinden farklıdır. Batı dünyası, Kutsal Batı Roma Germen İmparatorluğu ile Roma Katolik Kilisesi arasında iki kutuplu siyasi bölünmüşlük 
yaşarken geçmiş iki asırdır İslam dünyası bütünüyle parçalanmışlık sorunu yaşamaktadır. Yine Batı Dünyası hem kutsal metinle hem de kilise ve din adamlarıyla sorun yaşarken, İslam Dünyası'nın metin, cami ve din adamı merkezli toplumsal ve siyasal sorunlar yaşamış olduğunu söylemek zordur. Ayrıca Luther'in prensler tarafindan desteklenmesi ve kadim Germen-Roma mücadelesinin varlığı unutulmamalıdır. Varus Savaşı'nda (M.S. 9. yy.) Roma İmparatorluğunu püskürten Almanlar Luther üzerinden Roma'yı ikinci kez mağlup etmişlerdir.

Teolojisi, iman ve kurtuluş üzerinde yoğunlaşan Luther, Pavlusçu iman fikrini esas alan yaklaşımla insanın sadece İsa Mesih'e inanarak Tanrının adaletine layık olacağına ve kurtuluşa ereceğini ileri sürmüştür. Ferdin kurtuluşunu İsaMesih'e ve Kitab-1 Mukaddese kaydıran Luther, Hıristiyanlıktaki Latin-Yunan kültürünü dışlamak, kutsal kitabın yorum hakkını papalığın elinden almak, Hristiyan halkı kutsal metinle buluşturmak için Kitab-1 Mukkades'i Almanca'ya tercüme etmiştir (Aslan, 2003: 237-238). Bu bağlamda Roma-Katolik kilisesinin otoritesine yönelik reddiyeler içeren Luther'in 95 maddelik tezleri incelendiğinde özetle şunlar söylenebilir;

Tezlerine, günah çıkarmadan ayrı tutarak tövbe edilmesi gerektiği söylemiyle başlayan Luther, fiziksel/pratik karşıllğı olmayan içsel tövbenin anlamsız olduğunu, Papanın suç bağışlamasının garantörünün Tanrı olması gerektiğini aksi takdirde "Papa'nın affetmesi” diye bir şeyin olmayacağını ve Papa'nın kendi koyduğu hükümleri ortadan kaldıracağını/ bağışlayacağını, cezadan kurtarma vaatlerinin insanın tam kurtuluşa ereceğini bilmesinin söz konusu olamayacağını ve insanların aldatıldığını söyler. "Kulun cezasının Araf cezasına dönüştürülmesi” diye bir şeyin söz konusu olmayacağına, ölümün bir kurtuluş türü olduğuna, Cennet, Cehennem ve Araf'ın neliğine dair izahatlarda bulunur. Para kutularının varlı̆̆ının insan öğretisi olduğunu, bağışlanma belgesiyle selametten emin olanlarla bunun öğreticilerinin mahkum olduğunu iddia eden Luther'e göre, Araf'tan ruh satın almak Hristiyan'ca bir öğreti değildir. 
Ona göre Hristiyanlar Tanrı'nın lütfuyla Mesih ve kilisenin hayırlarından payını alır. Endüljansa bolluğu, cezaların gevşekliğine atfedilir. Papa bağışlanmasında dikkatli olmalı ve Endüljans, denilen şey papanın görüşüdür. Zenginlik sahiplerini avlamak için kullanılan Endüljans, yerine sosyal yardım yapılmalıdır. Bağışlanma belgesi, hayra götürmeyen kısmen cezadan azat eden bir ehliyettir. Tanrı'nın emri değil serbest iradenin bir kararı olan bu belgeyi satın almak aslında onun gazabını almaktır. Bağışlanma belgesiyle meşgul olmaktansa kelamla meşgul olmak daha efdaldir. Esas olan bağışlanma belgesi değil, Tanrının inayeti ve esas olan İncil'dir. İçsel/manevi insandan daha çok dişsal/beşeri insan vurgusunda bulunan Luther, Hıristiyanların ceza-ölüm-cehennem olgularını aşarak gayretkâr olarak Mesih'i takip etmeleri konusunda ögütlenmesi gerektiğini ve selamet yerine 1stırap yaşayarak Göklerin Melekutu'na varma çabası içinde olunması gerektiğini ifade eder (Luther, 2017).

Yine de Papa aracılığıyla bağışlanmaların küçümsenmemesi gerektiğini ifade eden Luther'in tezlerine bakıldığında kilisenin kurumsallaşmış Endüljans, dünyevi ve uhrevi hayata ipotek koymasıyla Tanrının yetkilerini ele almasıyla ilgili sorunu olduğu görülür. Endüljansların yanı sıra, papalık otorite ve yetkileriyle, ruhban sınıfının çeşitli uygulamalarını sorgulayan bir bildiri niteliğinde olan Luther tezleri; iman, kurtuluş, tövbe, dini otorite ve benzeri bütün reformist görüşlerinin özünü doksan beş maddelik tezinde işlemektedir (Erbaş, 2002: 203).

Avrupa'da, Sanayi Devriminin (19. yüzyıl) gerekse Teknoloji Devriminin (20. yüzyıl) ürettiği bilimsel, teknolojik, sosyal ve kültürel çeşitlilikler ve istilalar Hıristiyanlığın yok olmasına neden olmamıştır. Hıristiyanlığın mevcut formlara bürünmesiyle din, sekülerleşmiş ve bir ahlak olarak manevi ve bireysel bir alana indirgenmiştir. Bu olgusal durum M. Akif, C. Afgani ve M. İkbal gibi kişileri de etkilemiştir. Dinde tecdit aslı itibariyle reform, İslam toplumları için bir çıkış ve model olarak görülür. Yukarıda W. C. Smith'e atıfla ifade edildiği gibi Luther'e doğrudan olmasa bile gizil olarak içten içe bir atıfta bulunulmuştur. Esas olarak manevi alana indirgenen Protestanlıkta, dinine bağlı dindar bir insan onun hayati 
bir gerçeği olan Hıristiyanlığa bağlı bir birey olarak hesap verebilir. Buna benzer bir yaklaşımla İslam'ın geleceğine de paralel bir doğrultuda bakan yaklaşımlar vardır.

Batı örneğinden hareketle "İslam'ın reforme edilebileceği”ni ileri sürenlerin yanıldığı nokta Batı, Hıristiyanlığı "reforme" etmedi, ona karşı mücadele ederek dini yenmiştir. Mevcut dinin alt edilmesine ilaveten doğa bilimlerinin keşfettiği yeni buluşlar, sanayi ve teknik devrimler, politik ve sosyal devrimlerin önünü aydınlatarak ve güç katarak toplumun yapısını kökünden değiştirmiştir. Bilim, kültür, sanat, sosyal ve bireysel özgürlük alanındaki gelişmeler eski köhnemiş dinsel kurum ve ideolojiyi kiliseye hapsedip dini, toplumsal hayatın tüm alanlarından ç1karmış ve "bireyin özel bir meselesi”"ne dönüştürmüştür. Dinin ve "öteki dünya"nın yerine dünyay1, insanı ve toplumu yerleştirmiştir (Algül, 2018).

Avrupa'daki göçmen Müslümanlar, taşıdıkları kırsal özelliklerin çelişkiler taşıdığını veya yetmediği gerçeğiyle karşılaşmışlar, haliyle kendi köklerinden uzaklaşmışlardır. Yeni sosyal ve dinî bir yapıyla karşılaşan Avrupa'daki Müslüman toplumların yapısı radikal olarak değişmektedir. Farklı bir kültürel zeminle karşılaşan Müslümanlar, edindikleri yeni görünüm, düşünce ve yaşantı biçimleriyle geleneksel hayat tarzını terk etmişler ve farklı yaşam biçimlerin edinmişlerdir. Avrupa'ya geldikten sonra özgünlüklerini veya geleneksel değerlerini terk eden özellikle yeni kuşaktan olan Müslümanların İslam'a olan yaklaşımları ve İslamî yaşam biçimleri zayıflayarak farklılaşmıştır. Kendi kökleriyle uyuşmayan hatta çelişen tamamen yabancı bir mekanda yurt tutan Müslümanlar, karşılaştıkları farklı zeminin yarattığı gerilimleri aşmak için yeni yaklaşımlar ve (İslamî) yaşam biçimleri arayışına girmişlerdir. Bu bağlamda Batılı değerler olarak görülen demokrasiyi, çok kültürlülügü̈, hoşgörüyü ve sekülerliği içeren hayat tarzına uyum sağlama gereği duymuşlardır.

Müslümanların, özgünlükleri veya taşıdıkları mevcut değerlerin yetersizliğine ilişkin kuşkuları onları kurmaca bir dini anlayış biçimi ve bireysel bir kimlik arayışına itmiştir. Bir anlamda dayatılan içinde yaşadıkları toplumun değerleriyle 
uzlaşma zarureti bazı Müslüman entelektüel ve akademisyenleri zihinsel, psişik ve fiziksel alanda "yaşanılabilir" bir din anlayışı arayışına itmiştir. Bu durumun en büyük nedeni Batı düşüncesinin 4. yüzyıldan beri sahip olduğu mutlak "ben-öteki”" ayrımıdır. Batı tarihsel olarak dini, sosyal ve kültürel bakımdan biz ve onlar ayr1mını yapmıştır. Nitekim Kümbetoğlu'na göre bu ayrımın sınırlarını da algılanan kimlikler, grup sembolleri, gruplar arası ilişkiler, kurumlar ve kültürel pratikler oluşturur. Grupların birbirlerini tanımlama süreçleri özellikle entegrasyon süreçlerinde daha bir önem kazanır; gruplar arası etkileşimde farklı olarak algılanış, "temel değerler”i ortaya çıkarır (Akt. Subaşı, 2005: 86).

İslam'ın ve Müslümanların Batı coğrafyası ve kültürüyle karşılaşması neticesinde İslam'ın farklı bir kimlik edinmesi gerektiği iddiası dile getirilmiştir. "Euro-İslam" fikrinin bazı temsilcileri ve ilgilileri Bassam Tibi, Muhammed Hashas, Ziyaüddin Serdar, Tarık Ramazan, T. Abdurrahman, Tarı Oubrou ve Abdennour Bidar gibi kişilerdir. Bu kişilerden biri olan Hashas Batıyla olan ilişkileri Ortaçağ (7.-15. yy.), modern (1492-1945) ve post-kolonyalist dönem (1945 sonras1) diye 3 tarihsel aşamaya ayırır. Son dönem olan post-klasik din veya rasyonel iman anlamına gelen post-dini aşama, İslam'ın Avrupa'ya, Avrupa'nın İslam'a karşı dönemidir. İki dünya; modern-geleneksel, seküler-kutsal, fiziksel-metafiziksel şeklinde dikotomik ayrımlarla tasnif edilebilir. Bu bağlamda Euro-İslam, bu tarih ve gelenekleri kaynaştırmak için yeni fikir denemesidir (Hashas, 2013: 9). Tibi, göçmen Müslümanların reddetme ve kültürel gettoya katılma ikileminden kurtulması için asimile olmak yerine entegrizmi (bütünleşme) benimsemelerini önerir. Kültürler arası mutabakat karşılıklı feragatle olacaktır. Müslümanlar, İslam egemenliğini istemeyecekler veya dinin bir takım beklentilerini gerçekleştirmeyeceklerdir. Avrupalılar da etnik kimliklerinden vazgeçeceklerdir. Böylelikle demokrasinin ve insan haklarının vatanı olan Avrupa'da, Müslümanlar kendilerini ana vatanında (yurtlarında) hissedeceklerdir (Dağ, 2005: 58).

Müslümanların Avrupa'ya uyum sağlamasını sağlayacağı iddia edilen revizyonist-reformist veya geleneksel-modern yani modernliğin değerleriyle teolojik- 
siyasal olanı kuşatan “Avrupa İslam'ı” kavramı insanı ve modern değerleri kutsallaştırır ve modernliği sürekli kılar. İlahi olanı inkâr etmez, ancak onunla en büyük etik ve anlam kaynağı olarak çalışır. Helenist bir zihne sahip Euro-İslam teorisinde evrenin mirasçısı olan "Müslüman Prometheus”, Tanrı ile çatışmaz. İnsan, Tanrı ile bir "iş arkadaşı" olur. (Hashas, 2013: 45-46). Bu projede benimsenmiş olan "dünya-toplum-birey" içeriğine sahip Avrupa İslam'1; 1) Dünyayı kozmik refah için ilahi miras yoluyla insanileştirdiği, 2) Toplumsal varoluş için fıkıh yoluyla vahyi tarihselleştirdiğini 3) Bireysel varlık için etik özgürlüğün ilkesi aracıllğgıla bireysel inancı rasyonelleştirdiğini iddia eder. Böylelikle Batı Avrupa'nın seküler ve liberal değerleriyle uzlaşılabileceği iddia edilir ve anayasal demokrasilerde "içgüdüsel" bir biçimde güvence altına alır (Hashas, 2013: 41-42). Diğer bir Euro-İslam temsilcisi Faslı felsefeci Taha Abdurrahman insanlaşma-tarihselleşme-rasyonelleşme kavramlarını kullanarak Kuran ve modernite bağlamında bir okuma ve analiz yapar. Avrupa İslam'ı kavramını J. Rawls'ın siyasal çerçevenin açılımında kullanır (Hashas, 2013: 5).

Yenilgi psikolojisine ve apolojik tutuma dayanan Euro-İslam veya Avrupa İslam'1, geçmiş yüzyıllarda İslam'ın Helenleştirme/Batılılaştırma tecrübesini andıran yeni bir Helenleştirme/Batılılaştırma projesidir. Nitekim Tibi’ye göre Müslümanlar, Helenleşmiş İslam kaynaklarında ortak bir ahlak için kendilerine destekler bulabilirler. Tüm bunlara karşın kendisine yeni bir Luthercilik atfedilen Euro-İslam ise küreselleşme ve modernite sarmalında olan dünyada ehlileştirilmiş bir İslam arayışıdır. Euro-İslam için İslam; modern, seküler, demokrasi çerçevesine oturacak; içinde laikliği, kültürel modernliği ve ehl-i kitaba hoşgörüyü besleyen bir dindir (Alsayyad vd., 2004: 58-59).

\section{Dualiteler Bağlamında Euro-İslam}

İslam, Avrupa'nın sosyal, kültürel, siyasal ve dinî alanının önemli bir parçası olmakta buna bağlı olarak Müslümanların sayısı her geçen yıl artmaktadır. Hıristiyanlıktan sonra Avrupa'nın ikinci dini olan İslam ve 1960'larda Avrupa'ya 
ulaşan milyonlarca Müslüman göçmen, Avrupa'nın geleceğini değiştirdiği gibi reformasyondan beri Avrupa kıtasında dinî demografiyi de dönüştürmüştür. 1950'den beri Müslüman ülkelerden göçmen işçilerin geldiği Batı Avrupa'daki göçmenler, para kazanmak daha sonra ülkelerine dönmek amacındaydı fakat öyle olmadı, Avrupa'da kalmayı tercih ettiler. Müslüman göçmenler; Avrupa'nın coğrafi, demografik, ekonomik, sosyal ve siyasi yapısını değiştirdiler. Coğrafi olarak Müslümanların çoğu Avrupa'daki büyük kent merkezlerinin çevresindeki banliyölere yerleştiler. Demografik olarak Avrupa'daki Müslüman topluluklar; daha genç ve nüfus olarak daha çok artan bir özelliğe sahipler. Toplumsal olarak çoğunluğun aksine çok daha berbat ekonomik koşullara sahip olan Avrupa'daki Müslüman topluluğun etnik ve kültürel alt yapısına bakıldığında bölünmüş bir dini mezhep ve pratiğe sahip oldukları görülür (Ruiter, 2013: 2).

1950'li yıllarda Batı ülkelerinde 800.000 olan Müslüman nüfus günümüzde toplam 23 milyonu aşarak \% 5'lik bir orana ulaşmıştır. Her y1l 1 milyonu aşan sayıda Müslüman, Batı'ya göç etmektedir. 2050 yılında ise bu oranın \% 20'yi bulacağı tahmin edilmektedir (Dağ, 2016: 41). Yine 2025 yılında üç çocuktan birinin Müslüman ailelerden olacağı, 2050 yılında Avrupa kent merkezlerinin Müslümanlar tarafindan belirleneceği ifade edilmektedir. Yalnızca demografik radikal değişimler değil siyasal ve resmi yapıların da radikal olarak değişeceği iddia edilmektedir. Dinî bir ideoloji olarak yükselecek İslam'ın Müslüman savunucular, aktivistler ve akademisyenler tarafindan propagandasının yapılacak ve yayılacak olmasını kaygı edinen Batı, kendisinin İslam'ın meydan okumasına hazır olup olmadığını sorgulamaktadır (Francisco, 2007: 284).

Sanayileşme ve sömürgeciliğin yıkıc1 etkisi, Osmanlı sonrası sosyal ve siyasal parçalanmışlığa dayalı olarak inşa edilen devletler ve bu devletlerde despotik yönetimlerin desteklenmesi sorunlarını doğurmuştur. Gerek bu despotik yönetimlerin sultasından kaçan gerekse bu yönetimlerin (Libya, Yemen, Afganistan, Irak ve Suriye vs.) yıkılışı esnasında şiddete maruz kalan kitleler, Avrupa ülkelerine iltica etmişlerdir. Bir anlamda 20. ve 21. yüzyılda Avrupalılar, üretmiş oldukları kaosun 
hasatlarıyla kendi topraklarında karşı karşıya kalmışlardır. Kendilerini, Ortadoğu'daki despotizm, şiddet ve kaostan kurtarıp Avrupa'ya göçen Müslüman göçmenler arasında buldular. Karşılaşmış oldukları göç olgusu onları çözüm arayışlarına ve sorgulamalara itmiş̧ir. Kendilerinin büyük bir tehdit ve tehlikeyle karşı karşıya kaldıklarını düşünmüşlerdir.

Bu sorgulamalar, Batı'yı bazı açmaz ve ikilemlere itmektedir. Bu bağlamda Avrupa'da İslam'ın geleceğine dair iki senaryo var. Bunlardan biri, İngiliz-İsveç Yahudi Tarihçi Bat Ye'or tarafından terimleştirilen “Avrupa'nın İslamileşeceğini”" ifade eden "Eurabia" terimi diğeri tersine Bassam Tibi tarafindan kullanılan "İslam'ın Avrupalılaşması" gerektiğini ifade eden "Euro-İslam” kavramıdır. İslam ve Müslümanlara karşı korku tutumunu açıklayan Eurobia, Avrupa'da Euro-İslam senaryosundan daha çok desteklenen popüler bir algı olarak görünüyor. Eurobia senaryosu, uygarlıkların çatışması konuşulduğu anda İslam, konuşma özgürlüğüne ve Avrupa'nın sekülerleşmiş değerlerine tehdit olarak görülür. Eurobia senaryosunu destekleyen emareleri görünen İslamofobia tutumu, Euro- İslam senaryosunu destekleyen gelişmeleri görmede isteksizdir (Ruiter, 2013: 1-2). O. Fallaci, tarihçi B. Lewis, yazar R. Spencer ve Hollanda'lı siyasetçi G. Wilders gibi kişilere göre İslam, düşman olduğu dünya değerleriyle mukayese edilemez (Dağ, 2016: 42).

Kendisini "Hıristiyan bir ateist" olarak tanımlayan ve "Avrupa'yı İslam'a karşı koruyan tek kültürel ve entelektüel zırh, Hıristiyanlıktır" (Kalın, 2017: 43) diyen Fallaci "Avrupa artık Avrupa değil. O "Eurabia” bir İslam kolonisi. İslam'ın işgali yalnızca fiziksel anlamda değildir aynı zamanda zihinsel ve kültürel anlamdadır. Özgürlük kavramı ve düşünce özgürlüğ̈̈yle birlikte demokrasinin bu işgalciler tarafindan zehirlenmesi söz konusudur” (Fallaci, 2005: 1) diyerek, Carr Matt gibi felaket tellalları da "21. yüzyılın sonunda Avrupa şehirlerinin çoğunun Arapça konuşan göçmenler tarafindan istila edilecek ve kıtanın çoğu İslam şeriat hukuku altında olacaktır. Yahudiler ve Hristiyanlar, İslam denizinde azınlık olacak katedrallerin yerini cami ve minareler alacak ve kadınların çoğu burka giyecekler. ”şeklinde korku ütopyası oluştururlar (Ruiter, 2013: 5). 
B. Tibi'nin Arap Baharı ve 9/11'in siyasal ve psikolojik ortamında yazdığı “Political Islam” kitabı, siyasal İslam'ın Avrupa toprakları üzerinden nasıl tasfiye olacağı meselesi üzerine odaklanır. Ona göre İslam dünyasından olan bir kişi, şeriatı ve Avrupa'daki İslam'1 reforme edebilir ve yeniden düşünebilir. Müslümanların, Avrupalılaşma ve çoğulculuğu kuşatma üzerine temellenmiş "Euro-İslam" kavramı öncülügünde cihat ve dava gibi şeriatın bazı unsurlarını terk etmeleri gerekmektedir ve bu yapılabilir. Avrupa'nın İslamlaşmasını talep eden İslamcılar, Avrupa kimliğine ve medeni açık topluma tehdit olarak görülür (Tibi, 2014: XIV).

İslam'ın reforme edilebileceğini savunan Tibi’ye göre Müslüman göçmenler, Avrupa ve onun kültürel sistemiyle harmoni olmuş ve Avrupa'ya kimliklerini getirmişlerdir. (Tibi, 2007). Ramazan ise yeni Avrupalı Müslüman kimliği yaratma çağrısında bulunur ve Müslümanları Avrupa'nın sosyal ve kültürel hayatına katılmaya davet eder. İslami ilkelerin Batı Avrupa kültürel gerçekliğine dayandırılabileceğini ve kök kültürlerinden ayırabileceğini savunur. Ona göre İslam, Avrupa toplumuna şu unsurlarla adapte edilebilir; 1. İslami siyasal ve uygar liderlerin ve İslami derneklerin ortaya çıkışıyla 2. Dini otoritede değişikliklerle 3. Azınlık kültürü olarak İslam statüsünün tanımındaki değişikliklerle 4. Şeriatın manasını yorumlamada değişikliklerle ve 5. Cinsiyet eşitliği arzusuyla mümkündür. Bu süreçte en önemli vazife ve işlevler siyasal ve kamu liderlerine ve derneklere atfedilir. Avrupalı Müslüman liderleri, Avrupa'da İslam'ın barınmasında önemli rol oynayacaklardır. Avrupa'da şeriatın anlamı değiştirilerek bir tehdit olarak görülen "Eurobia" senaryosundan kurtulabilir (Ruiter, 2013: 13).

Gerek Tibi gibi Müslüman düşünürler gerekse Batılı yaşam tarzı için en sorunlu kavram çifti; Dar'ül İslam ve Dar'ül Harp kavramlarıdır. Dünya, Dar'ül İslam ve Dar'ül Harp diye ikiye ayrılmıştır. Evrensel bir din olarak İslam ya inananlar ya da maruz topluluklar olarak Müslüman idaresinde altında yaşayacak olan tüm insanlarda küresel siyasal düzeni genişletir. Bu amacı başarmak için özgür, erkek yetişkin Müslümanlar Allah yolunda mücadele etmekte yükümlüdür. Dar'ül İslam tarafından ele geçirilmesi yeterli değil, İslam'ın zaferiyle sonlanmalıdır 
(Francisco, 2007: 284). İslam'ın böyle bir devlet ve siyasal düzen talebi yani siyasallaşmasının İslamlaşmayı doğuracağını düşünen Luther, Batılıların gelecekte kendilerini Dar'ül İslam düzeninde Müslümanlar arasında yaşar olarak bulacağını iddia eder. O bu düzeni "Mahometisch Reich olarak” isimlendirir (Francisco, 2007: 290).

Müslümanlara yönelik "yetersizlik" ve "uyumsuzluk" vurguları, El Kaide, İŞİD, Boko Haram, Eşşebab gibi örgütlerin varlığından dolayı "terörist” imalarının yanında, olgudan daha çok bir algı durumu olan "islamofobia" ile icbar politik tutumları Müslümanların Avrupa'daki varlığını olumsuzlamıştır. Müslümanların hem sayısal olarak hem de dinî yaşam biçimleri Eurobia/Avrobistan ve Euro-İslam senaryosunu ortaya çıkarmıştır. Bu ikili senaryo bağlamında hegemonyayı derinleştirme psikozu olan "yetersizlik" yanılgısından hareketle Euro-İslam, "islamsızlaştırma" ve hegemonik bir dayatma projesi olarak görülebilir.

Batı ile Doğu'nun mücadelesi veya düşmanlığı uzun yıllara dayanmaktadır. Grek/Helen döneminde olan mücadele, İskender'in Doğu seferiyle doğrudan çatışma ve savaşa dönüşmüştür. Sonraki yıllarda İslam'ın meydan okuyucu bir biçimde ortaya çıkışı bu mücadele veya düşmanlığın boyutunu değiştirmiştir. Hristiyanlığın kalbi olarak görülen Greko-Roman ve Judeo-Hıristiyan mirasla, Müslüman dünya geçmişte karşılıklı olarak çatışma içerisinde bulunmuştur (Hashas, 2013: 10). Tarihsel kod olarak İslam'a dolayısıyla Müslümanlara önyargılı olan Batı uygarlığının düşmanlığı, Ortaçağ dönemlerine kadar gider. Ortaçağ döneminin kanuni esası haline gelen Hıristiyanlığın Muhammed'e karşı düşmanlığı ya da Avrupa'nın İslam'la ve Müslüman dünyayla ilişkisi daha milli boyut kazanmıştır. Bu anlamda milli devletle ilişkili olan İslam korkusu, ortaçă̆ kanonundan ve $\mathrm{Mu}$ hammed'e karşı olan Hristiyanlık düşmanlığından miras alınmış, fakat farklı bir milli yoldan devam etmektedir (Geisser, 2004: 37-38).

18. yüzyılın başında İsa'nın düşmanlarının topraklarında düşman olarak görülen İslam ve coğrafyası üzerinde ekonomik, teknik, askeri, siyasi ve kültürel bir üstünlük kurulmuştur. 19. yüzyılın ortasından sonra İslam dünyasının büyük 
kısmı Avrupa güçlerinin ittifakıyla ve emperyalizmle yüzleşmiştir (Dağ, 2016; 39). 20. ve 21. yüzyılda Avrupa'ya yapılan Müslümanların göçleri İslam ve Müslümanlardan duyulan rahatsızlı̆̆ı nüksettirmiştir. İslamfobia’ya karşın Westophobia'nın varlığ1 da bir gerçekliktir. Batı kültürünün çöküş ve boşlukta olduğuna dair ve abartılı bir biçimde batılı toplumda ahlaki bir çöküntü içinde olduğuna dair abartılı bir yaklaşım biçimi Westophobia söz konusudur (Ruiter, 2013: 10). İslamofobia kadar yaygın olmayan Westophobia da sağlıklı bir durum değildir. Bu bağlamda kısmen İslamobik yaklaşımlara sahip oryantalizm ne kadar sorunlu ise Westophobia'nın yansımasının bir terimi olan oksidentalizm de aynı derecede sorunludur.

Riddel ve Cotterel'e göre Batılı ve Müslüman toplumlar arasında yeni antipati nedenleri vardır. Bunlar şunlardır; İsrail-Filistin çatışması, Irak’a karşı BM yaptırımları, Suudi Arabistan'da Amerika askerinin varlığı, İslami kutsal metinde Müslüman olmayanların negatif topolojisi, tarihi miras, küreselleşme, Müslüman medyasında Westophobia ve komplo teorileridir (Ruiter, 2013: 11). Bu dualiteyi aşmanın yolu olarak Tibi'nin önerdiği ve talep ettiği birtakım şeyler vardır. Ona göre Avrupalıların, kibirlerini yenmeleri ve Müslümanlara karşı olumsuz bakışlarını terk etmeleri gerekir ve göçmen Müslümanlar Avrupalı-Müslüman kimliğini yaymaları gerekir (Tibi, 2001: 225-227). Teorik zeminini Habermas'tan alan Tibi, Müslüman kimliği Avrupa vatandaşlık kültürüne uyarlama çabasındadır. Çok kültürlülük, sekülerleşme, tolerans, çoğulcu kimlikler ve bireyselleşme gibi unsurlar içeren homojenleşmeden daha çok heterojenleşmeye vurguda bulunan örgütsel kimliğin terk edilerek yerine bireysel kimliğin inşasını olumlayan post-modern temalar da taşımaktadır. Oysa bu talep İslam'ın yardımlaşma, dayanışma/tesanüd, kültürleşme ve uhuvvet gibi unsurlarını çözecek ve Müslüman kimliği parçalanmasina neden olacak bir taleptir.

\section{Sonuç}

Doğal olaylardan çok farklı bir yapıya sahip olan sosyal olayların nasıl olacağ1 ve neler getireceği doğal olaylar gibi önceden kestirilemez. Kendi coğrafyas1- 
nın dışına sarkan ve bu coğrafyalarda emperyalist politikalar uygulayan Batı dünyası, doğuyu dolayısıyla çoğunlukla Müslümanları kendi topraklarında bulacağını tahmin etmiyordu. Avrupa'daki Müslüman sayısı şimdilerde 20 milyon küsurken 2050 yılında ise Avrupa nüfusunun 5/1'inin Müslüman olacağı tahmin edilmektedir. Müslümanların Avrupa'nın en genç nüfusuna sahip oluşları, hem göç hem de doğum oranlarının yüksek oluşu yaşlı Avrupa'yı ciddi ciddi düşündürmektedir. Avrupalı Hristiyanların yaklaşık yarısı, İslam'ı Avrupa Uygarlığına tehdit ve düşman olarak görmektedir. İslam’a karşı yükselen sosyal, siyasi ve kültürel bir düşmanlığın artan varlığı düşünüldüğünde bu oranın daha da artacağı aşikârdır. Ayrıca otantik/sahih İslam, Avrupa için hep tarihsel olarak bir korku ve tehdit unsuru olarak görülmüştür.

İslam'ın ve Müslümanların kendi içinde yaşamış olduğu sosyal, siyasal, kültürel ve iktisadi sorunlar, Batı toplumlarının Müslümanlara tarihsel olan olumsuz bakışını daha da perçinlemektedir. İki yüz yıllık bir kuşatma ve sömürgeleşme tecrübesiyle karşı karşıya kalan İslam toplulukları, hem bireysel olarak hem de toplumsal olarak özgüven sorunu yaşamaktadırlar. Yaşadıkları bu özgüven sorunu nedeniyle içinde bulundukları toplumda "tedirgin" ve "yabani” davranışlara neden olmaktadır. 200 yıldır kimyasıyla oynanan bir topluluğun başka tepkiler vermesini beklemek oldukça yanlıştır. Tüm bu sorunların yaşandığı Avrupa'da "Euro- İslam" veya “Avrupa İslam'”" denilen bir projenin veya söylemin ortaya konulması gayet normaldir. Yaşanan bir kriz ve açmazı bu tür bir projeyle aşma çabasını mahkum etmek veya bu amaç içinde olanların "kullanıldıklarını" zem etmek de doğru olmaz ve abartı olur. Fakat bu kişilerin en önemli sorunu apolojist bir tutum kazanmalarının neticesinde "savunma ve yenilgi" psikolojisine bürünüp "uygarlık" kompleksine tutulmalarıdır. Yaşadıkları bu kompleks "İslam'ın medeni olmadığı, şiddet içerdiği veya şiddet içeren yapılar ürettiğine" dair tezleri bir anlamda olumlamış ve Avrupa İslam'ı gibi bir tezi ortaya koymalarına yol açmıştır.

Farklı kültürel kodlarına ve yaşam tarzlarına sahip Avrupa'da yaşayan göçmen Müslümanların kendi ülkelerinden getirmiş oldukları gelenek kodlarıyla 
yoğrulmuş olan din anlayışı ile yaşamalarının bir takım paradokslar doğurması gayet doğaldır. Bu açmazın aşılması çabasında mevcut Avrupa değerlerini ana nirengi noktası alınması durumu İslam'ın dinamikleri ve iddialarıyla çelişen bir durumdur. Çünkü İslam, fizik/yaşayış ve metafizik/inanç alanlarında dominant olan hükümlere sahip bir dindir. Nitekim Hz. Peygamber zamanında Medine'de Müslümanlar, \%15 oranında bir nüfusa sahip olmasına rağmen gerek toplumsal hayatı yaşamada gerekse siyasal yönetim biçiminin belirlenmesinde etkin olmuşlardır. Müslümanların idarenin oluşumunda ve vasatın oluşmasında ve şehirde yaşam şartlarına dair düzenlemelerdeki etkisi bu belirleyiciliği göstermektedir.

İslam mevcut haliyle Avrupa'nın kabulleneceği bir din değil. Bu bilindiği için İslam'ın kodları ve hükümlerinde değişiklik yapılması gerektiği Batı'nın aklında hep bir apriori önerme olarak durmaktadır. Nitekim bu önermeyi dile getiren sayısızca haber, söylev, makale ve kitap bulunmaktadır. Bu bağlamda şimdilerde Sarkozy ve 300 aydının Kuran'da olan bazı hükümlerin çıkarılmasına yönelik talepleri yine Macron'un Müslüman danışmanı Hakim el Karaui'nin hazırladığı rapor doğrultusunda inşa edeceğini iddia ettiği “Fransa İslam'ı" Batı'nın üniformist ve monolitik karakterini ortaya koyan teşebbüslerdir. Avrupa İslam’ı tartışmalarının bir yansıması olan Fransız İslam'1 projesi, var olan dernek ve kurumların feshedilmesi yerine çatı örgüt olarak “Fransız İslam’ı için Müslüman Derneği (AMIF)" kurulmasinı planliyor.

$\mathrm{Bu}$ tür proje ve planların haklı nedenlerinin olmadığı da söylenemez. Suudi Arabistan finansına dayalı selefi hareketlerin şiddete yönelebilen içeriğe sahip olması, devletlerin kendi ülkelerinden göndermiş oldukları imamların, orada doğmuş ve büyümüş olan nesilleri anlamakta ve onlara hitap etmekte zorlanışı, yine Almanya örneğinde yaşadığımız gibi (orada bulunan dernek ve vakıfların vesile olmasından dolayı) ülkemiz vatandaşlarının yıllarca edindikleri maddi kazanımların dolandırılması ve bu dernek ve vakıfların para akışlarının şeffaf olmayışı bazı önemli sorunlardandır. Fakat Fransa'nın, bu unsurların ilki dışında Müslümanlara dair duymuş olduğu bir kaygısının olduğu söylenemez. Özellikle devletlerin kendi 
ülkelerinde yaşayan Müslüman topluklarla İslam üzerinden kurmuş olduğu münasebeti ve bu nüfusu kontrol etme çabaları Fransa gibi ülkeler kendi ülkelerinin iç meselelerine müdahale olarak yorumlamaktadırlar. 200 ylllık sömürgeleştirme yeteneğine sahip bir mirası tevarüs eden Fransa, "kolonileştirme" ve "asimilasyon" geleneğinin bir devamcısı olarak İslam topluluklarını "entegrasyon” adına sömürgeleştirmektir. Kendi istediği standartlardaki aydın ve alimleri desteklerken bunların dışındakileri yeri geldikçe tasfiye eden bir yaklaşım sunmaktadır. Nitekim, Fransa İslam'ı söylemini İslam'ın ana omurgasına dokunmadan ortaya koymaya çalışan T. Ramazan'ın taciz iddiasıyla tutuklanması durumu Fransa İslam'ı söyleminden ayr1 tutulamaz.

Hem üniformist yapısıyla hem de "ötekileştirici” tutumuyla Avrupa, Euroİslam söylemiyle bile yetinmemektedir. İslam'ın varlığını kendi ülke topraklarında görmeye tahammülü olduğu söylenemez olan Avrupa, tarihsel bir düşman olarak gördüğ̈̈ İslam'ı muteber bir muhatap olarak görmemektedir. Ülkelerinde yaşayan Müslüman toplumları izbe ve dar mekanlara hapsedip, kurumlarını da kısıtlı koşul ve imkanlara mahkum ederken, Fallaci'nin dediği gibi “tek zırh olan” Hıristiyanlık ve Batılı Hıristiyan toplumlar için devasa mimariye ve genişliğe sahip kilise ve katedraller inşa ederken dernek ve kurumlarına ise devasa imkanlar sağlanmaktadır. Bir anlamda lisan-1 hal ile Müslüman tebaaya "ya izbe mekanlarda inancınızı yaşarsınız ya hayat tarzımız olan sekülerleşmeyi yaşarsınız ya da inanca ihtiyacınız varsa daha cazip unsurlara sahip ve imkanları bol olan Hristiyanlık dinine irtidat edersiniz" denmektedir.

Yine ilk nesil Müslüman göçmenler; adet, gelenek ve göreneklere dayanan yaşam tarzını koruyup milli siyaset ve milli dilde 1srarlı ve hayatlarında İslam'1 önemli görürlerken yeni neslin bu tür hassasiyetlerinin zayıfladığ dir. Demokratik bir görünüme sahip sekülerleşme, Avrupa kimliğinin bir unsuru olarak dönüştürücü ve asimile edici ideolojik bir içeriğe ve işleve sahiptir. İdeolojik tutum içeren sekülerleş(tir)me millî ve dinî hassasiyetleri zayıflamış olan gençlerin 
üzerinde sofistik bir biçimde uygulanmaktadır ve nitekim bunun neticesinde Avrupa'da Müslüman genç topluluklar sekülerleşme sürecine dahil olmuşlardır.

Özet olarak, Avrupa; Müslümanları ehlileştiremediği takdirde onlara karşı hırçın ve onları inkar edici olma sürecini yaşamaktadır. "Ehlileşmiş" olarak kabul etmediklerini kapı dışarı etmeye yakın bir tavır içerisine girmiştir. Müslüman devletler, kurumlar ve aydınların yapması gereken oksidentalizme veya westophobia durumuna düşmeden Batı devlet, kurum ve aydınlarını iki yüzlülükten vazgeçmeye davet etme, islomafobik tutumdan vazgeçmelerine çağrıda bulunma ve kendi dışında olan insanların adet, gelenek ve inançlarına saygı duymaya yönelik hatırlatmalarda bulunmak olmalıdır.

"Euro-İslam" söyleminin bir ümit ve fantezi olmasını sağlayan nedenler; Batı'lı devletlerin eurosantirik olmasının yanında sermaye, teknik, siyasal, askeri güç ve bilimleri yönetmede hakim güç olmalarıdır. Maddi ve beşeri hayatın kaidesi şudur; "Belirleyemiyorsanız her açıdan belirlenirsiniz". Nitekim bu kaide gereğince belirleyici olmaktan uzak olan İslam dünyası 200 yıldır belirlenmektedir. İslam dünyasının akademisyen, düşünür ve aydınlarının esas vazifesi yeni bir İslam türü üretmekten daha çok toplumlarına nasıl katkıda bulunacağına ve bilime vereceği katkıların ne olacağına yönelik bir muhasebe ortaya koymak olmalıdır.

\section{Kaynaklar}

Algül, R. (2018). Avrupa'daki Sosyal Hayat ve "Euro-İslam", 15 Mayıs. http://hallac.org/index.php?id=6\&tx_ttnews\%5Btt_news\%5D=499\&cHash=49f91 da4216c94acee6f133816b4f8b0\&PHPSESSID=6b3340901bb45f74a2543bc94403 380e, 15 Mayıs 2018.

Alsayyad, N. (2004). Müslüman Avrupa ya da avro-İslam. (1. Basım). İstanbul: Everest Yayınları.

Aslan, A. (2003). Martin Luther. TDV İslam Ansiklopedisi. 34, 237-238.

Dağ, A. (2005). Melezleştirmenin diğer adı: euro-İ̀slam. Umran Dergisi. 128, 58-61. 
Dağ, A. (2016). Íslamofobia: hegemonyayı derinleştirme ve bir hegemonya projesi olarak euro-islam, I. Uluslararası Sosyal Bilimler ve Müslümanlar Kongresi: "Hegemonya Karşı Hegemonya”, Konya: 5-7 Mayıs.

Erbaş, A. (2001). Protestan reformu ve Luther, 2000. Yılında Hıristiyanlık (Dünü, Bugünü ve Geleceği), Ankara.

Fallaci, O. (2005). İnterwiew. Wall Street Journal. 23 Haziran.

Farajae, İ. A. (2013), Amerika Birleşik Devletleri’nde İslam’ın Tarihi. (Çev. Celal Emanet). Recep Tayyip Erdoğan Üniversitesi İlahiyat Fakültesi Dergisi. 4, 267-281.

Francisco, A. S. (2007). Luther, lutheranism, and the challenge of 1slam. Concordia Theological Quarterly, 71. (3), 283-300.

Friedman, T. L. (2002). An islamic reformation, https://www.nytimes.com/2002/12/04/ opinion/an-islamic-reformation.html, 11 Mayıs 2018.

Geisser, V. (2004). Islamophobia in Europe: From the Christian Anti-Muslim Prejudice to A Modern Form of Racism. Islamophobia and Its Consequences on Young People. Seminar Report, Hungary: European Youth Centre Budapest.

Gülyeşil, M. O. (2017). Avrupa islam'1: entegrasyondan din reformuna, https://www. aa.com.tr/tr/analiz-haber/avrupa-islami-entegrasyondan-din-reformuna/870650, 1 Mayıs 2018.

Hashas, M. (2013). On The Idea of European Islam Voices of Perpetual Modernity. PhD Thesis, Italy: LUISS University of Rome.

Kalın, İ. (2017). Ben, öteki ve ötesi. (13. Basım). İstanbul: İnsan Yayınları.

Luther, M. (2017). Doksan beş tez. (Çev. C. Çevik). (1. Basım) İstanbul: İş Bankası Yayınlar1.

Madany, B. M. (2018). Euro-Islam, or IslamizedEurope?, 22 Mart, http//www.unashamedofthegospel. org/euro-islam-or-islamized-europe.cfm. 05 Haziran 2018.

Nietzsche, F. (2010a). Güç istenci. (Çev. Nilüfer Epçeli). İstanbul: Say Yayınları.

Öztürk, M. (2003). Tefsir tarihinde ehl-i Kur'an ekolü. Tefsir Tarihinde Ehli Kur'an Ekolü. $3,(1), 167-200$.

Ruiter, Bert de. (2013). The Future of İslam in Europe, 2 Nisan 2016, http://www.sharing lives. eu/wp-content/uploads/2013/03/The-Future-of-Islam-in-Europe-Bert-de-Rui ter.pdf. 10 Haziran 2018.

Smith, W. C. (1953). Modern Türkiye Dini Bir Reforma mı Gidiyor?, AÜIFFD. (1), 7-20. 
Subaşı, N. (2005). Gecikmiş Bir Kimlik Tartışması Olarak Euro-İslam. Karizma Dergisi. (24), 85-95.

Tibi, B. (2001). Islam Between Culture and Politics. Newyork: Palgrave.

Tibi, B. (2007). Europeanisation, not Islamisation, http://www.signandsight.com/features/ 1258.html, 13 Kasım 2018.

Tibi, B. (2014). Political İslam, World Politics and Europe: From Jihadist to Institutional Islamism. London: Routledge. 